\title{
Komentarz do art. 26-27 ustawy z dnia 9 czerwca 2011 r. - Prawo geologiczne i górnicze (Dz.U. 2021, poz. 1420 ze zm.)
}

Art. 26.

1. We wniosku o udzielenie koncesji na wydobywanie kopalin ze złóż określa się również:

1) złoże kopaliny lub jego część, która ma być przedmiotem wydobycia;

2) wielkość i sposób zamierzonego wydobycia kopaliny;

3) stopień zamierzonego wykorzystania zasobów złoża kopaliny, w tym kopalin towarzyszących i współwystępujących użytecznych pierwiastków śladowych, jak również środki umożliwiające osiągnięcie tego celu, a w przypadku wód leczniczych, wód termalnych i solanek - zasoby eksploatacyjne ujęcia;

4) projektowane położenie obszaru górniczego i terenu górniczego, przedstawione zgodnie z wymaganiami dotyczącymi map górniczych, z zaznaczeniem granic podziału terytorialnego kraju;

5) geologiczne i hydrogeologiczne warunki wydobycia, a w razie potrzeby warunki wtlaczania wód do górotworu.

2. Do wniosku, o którym mowa w ust. 1, dołącza się dowody istnienia:

1) prawa do korzystania $z$ informacji geologicznej, jakie w zakresie niezbędnym do prowadzenia zamierzonej działalności przysługuje wnioskodawcy, oraz kopię decyzji zatwierdzającej dokumentację geologiczną; 
2) prawa przysługującego wnioskodawcy do nieruchomości gruntowej, w granicach której ma być wykonywana zamierzona działalność w zakresie wydobywania kopaliny metodą odkrywkową, lub dowód przyrzeczenia jego ustanowienia. Obowiązek ten nie dotyczy węgla brunatnego.

3. Do wniosku, o którym mowa w ust. 1, dołącza się projekt zagospodarowania złoża, określający wymagania $w$ zakresie racjonalnej gospodarki złożem kopaliny, w szczególności przez kompleksowe i racjonalne wykorzystanie kopaliny głównej i kopalin towarzyszących, oraz technologii eksploatacji zapewniającej ograniczenie ujemnych wpływów na środowisko. Obowiązek ten nie dotyczy koncesji udzielanych przez starostę.

3a. Projekt zagospodarowania złoża dotyczący zlóż kopalin określonych w art. 10 ust. 1, z wyłączeniem złóż węglowodorów, podlega zaopiniowaniu przez wlaściwy organ nadzoru górniczego. Organ nadzoru górniczego wydaje wnioskodawcy opinię $w$ terminie 14 dni od dnia doręczenia projektu zagospodarowania złoża. W przypadku niewyrażenia opinii w tym terminie uważa się, że organ nadzoru górniczego nie zglasza uwag.

3b. Do wniosku, o którym mowa w ust. 1, dołącza się opinię, o której mowa w ust. 3a, albo informację o jej braku, a w przypadku zgłoszenia uwag także oświadczenie o sposobie ich uwzględnienia lub przyczynach ich nieuwzględnienia.

4. We wniosku o udzielenie koncesji przez starostę określa się również przewidywany sposób prowadzenia ruchu zakładu górniczego, uwzględniający wymagania określone w art. 108 ust. 2, oraz prognozowany sposób likwidacji zakładu górniczego, uwzględniający obowiązki określone w art. 129 ust. 1.

5. Minister właściwy do spraw środowiska określi, w drodze rozporządzenia, szczególowe wymagania dotyczące projektów zagospodarowania złóż, kierując się potrzebą zapewnienia racjonalnej gospodarki złożem, ochrony środowiska oraz zapewnienia ochrony zdrowia i życia ludzkiego.

Komentowany artykuł określa tzw. dodatkowe (w stosunku do wynikających $\mathrm{z}$ art. 24) wymagania dotyczące wniosku o koncesję na wydobywanie kopaliny ze złoża. Dalsze rozwiązania dotyczą z kolei koncesji na wydobywanie węglowodorów (art. 49ea oraz nast. pr.g.g.). Określenie „złoże kopaliny lub jego część, która ma być przedmiotem wydobycia" oznacza konieczność wskazania zarówno rodzaju kopaliny, jak i nazwy takiego złoża w sposób odpowiadający informacjom stanowiącym treść jego dokumentacji geologicznej. Ustawa nie przesądza, jaka „część” złoża może stać się przedmiotem koncesji na jego wydobywanie. Przede wszystkim niekoniecznie musi to być część złoża (w zna- 
czeniu geologicznym) objęta odrębną dokumentacją geologiczną. W ustawie nie sprecyzowano wielkości tak wyodrębnionej części. Jak wynika z art. 29 ust. 1 pr.g.g., przesłanką odmowy koncesji jest ustalenie, że zamierzona działalność sprzeciwiałaby się interesowi publicznemu, w tym racjonalnej gospodarce złożem kopaliny. Wydaje się więc, że odpowiedź na pytanie, czy dana „część” złoża może być przedmiotem odrębnej koncesji na wydobywanie kopaliny, tkwi w sposobie rozumienia przesłanki określonej jako „racjonalna gospodarka złożem”. Jeżeli przedmiotem koncesji ma być część złoża, to niezbędne stanie się wskazanie wielkości jej powierzchni oraz jej lokalizacji.

Pojęcie „racjonalnej gospodarki” nie zostało nigdzie zdefiniowane. „Racjonalny” oznacza tyle co ,oparty na nowoczesnych metodach naukowych; dobrze przemyślany i uzasadniony" ", z kolei „gospodarowanie” wypada traktować jako synonim „korzystania”. Problem jednak w tym, że ustalenie sposobu rozumienia „racjonalnej gospodarki złożem kopaliny” możliwe jest wyłącznie w odniesieniu do skonkretyzowanego stanu faktycznego, a ponadto czynniki kształtujące wspomnianą przesłankę (technologiczne, ekonomiczne) mogą ulegać przewartościowaniom $^{2}$. Wskazane jest, by rozważnie postępujący wnioskodawca ubiegający się o koncesję na wydobywanie kopaliny z „części” złoża wykazał, że nie zagrozi to racjonalnej gospodarce pozostałą częścią złoża.

Zwrot „wielkość i sposób zamierzonego wydobycia kopaliny” oznacza przede wszystkim konieczność określenia ilości kopaliny. W zasadzie nie może ona być większa od zasobów geologicznych określonych w dokumentacji geologicznej. Sposób wydobywania (metodą odkrywkową, podziemną, otworową) przeważnie determinowany jest rodzajem kopaliny oraz warunkami występowania jej złoża, a zwłaszcza głębokością jego zalegania. Niekiedy szczegóły mogą być pochodną uwarunkowań ekonomicznych i środowiskowych. Przykładem może być siarka, którą można wydobywać zarówno metodą odkrywkową, jak i metodą otworową (podziemne wytapianie). Co prawda współcześnie węgiel brunatny wydobywa się wyłącznie odkrywkowo, ale w przeszłości stosowano w jego przypadku także metodę robót podziemnych.

Pojęcie „stopień wykorzystania zasobów złoża” nie zostało zdefiniowane normatywnie, aczkolwiek pojawia się w tekstach aktów normatywnych. W literaturze technicznej przyjmuje się, że jest to część wykorzystanych zasobów złoża odniesiona do jego zasobów, wyrażona w procentach lub ułamku dziesiętnym $^{3}$. W istocie wskaźnik ten oznacza maksymalną wielkość zasobów możli-

${ }^{1}$ Mały słownik języka polskiego. Red. S. Skorupka, H. Auderska, Z. Łempicka, Państwowe Wydawnictwo Naukowe, Warszawa 1969, s. 683.

${ }^{2}$ Zob. wyrok NSA z dnia 13 stycznia 2015 r., sygn. II GSK 1841/13; wyrok NSA z dnia 1 grudnia 2015 r., sygn. II OSK 2323/15.

${ }^{3}$ W. Glapa, J.I. Korzeniowski: Mały leksykon górnictwa odkrywkowego. Wydawnictwa i Szkolenia Górnicze Burnat \& Korzeniowski, Wrocław 2005, s. 96. 
wych do wydobycia ${ }^{4}$. Biorąc jednak pod uwagę chociażby konstrukcję zakładającą, że każda dokumentacja geologiczna (w tym dokumentacja złoża kopaliny) de facto stanowi zbiór informacji nie do końca zweryfikowanych, nie sposób wykluczyć, że rzeczywista wielkość wydobycia może przekraczać ustaloną na podstawie wspomnianego wskaźnika.

Wskazanie stopnia zamierzonego wykorzystania zasobów złoża (w tym kopalin towarzyszących ${ }^{5}$ i współwystępujących użytecznych pierwiastków śladowych) bezspornie ma na celu racjonalną gospodarkę złożem kopaliny, rozumianą jako najpełniejsze - w uwarunkowaniach ekonomicznych i technologicznych istniejących w dniu złożenia wniosku koncesyjnego - wykorzystanie zasobów złoża, zwłaszcza wielosurowcowego. Przez ,środki umożliwiające osiągnięcie celu" określonego w art. 26 ust. 1 pkt 3 pr.g.g. należy rozumieć rozwiązania technologiczne i organizatorskie zmierzające do jak najpełniejszego wybrania zasobów złoża. Co prawda we wspomnianym przepisie posłużono się sformułowaniem „wykorzystywanie zasobów złoża”, ale bezspornie postępowanie z wydobytą kopaliną (główną, towarzyszącą, współwystępującymi użytecznymi pierwiastkami śladowymi) stanowi w znacznej mierze pochodną relacji ekonomicznych i nie jest przedmiotem komentowanej ustawy. Przedsiębiorca, który rozporządził wydobytą kopaliną, w praktyce nie ma wpływu na to, jak będzie się z nią dalej postępować. Z kolei o zaliczeniu określonych substancji do kopalin towarzyszących lub użytecznych pierwiastków śladowych przesądzi treść dokumentacji geologicznej.

„Zasoby eksploatacyjne ujęcia” nie zostały zdefiniowane w żadnym akcie normatywnym. W hydrogeologii rozumiane są jako „dopuszczalna ilość (pobór)

\footnotetext{
${ }^{4}$ Zob. np. wyrok NSA z dnia 1 grudnia 2015 r., sygn. II OSK 2323/15.

5 „Kopalina towarzysząca” nie doczekała się definicji ustawowej. Przyjmuje się, że chodzi tu o kopalinę tworzącą naturalne nagromadzenie w obrębie lub w bliskim sąsiedztwie kopaliny określonej jako „główna”, a jej wydobywanie nie jest podstawowym celem przedsiębiorcy, ale może przynieść korzyść gospodarczą, gdy idzie w parze z wydobywaniem kopaliny głównej. Ustalenie szczegółów może być niezwykle trudne. (Zob. T. Ratajczak, E. Hycnar: Kopaliny towarzyszace w złożach węgla brunatnego. T. 1: Geologiczno-surowcowe aspekty zagospodarowania kopalin towarzyszacych. Wydawnictwo IGSMiE PAN, Kraków 2017, s. 18 i nast.; R. Uberman, M. Nieć: Kopaliny towarzyszace - problemy dokumentowania, wydobycia i oplat eksploatacyjnych. „Górnictwo Odkrywkowe” 2014, nr 2/3, s. 33; R. Uberman: Kopaliny towarzyszace $w$ złożach węgla brunatnego. T. 2: Prawno-ekonomiczne oraz górnicze aspekty zagospodarowania kopalin towarzyszacych. Wydawnictwo IGSMiE PAN, Kraków 2017, s. 15). Inni autorzy określają ją jako „współwystępującą” (w granicach lub w bliskim sąsiedztwie złoża kopaliny głównej); może ona być eksploatowana razem z kopaliną główną, a nie kwalifikuje się do samodzielnej eksploatacji (W. Glapa, J.I. Korzeniowski: Mały leksykon..., s. 44). Trudność polega jednak na tym, że Prawo geologiczne i górnicze zna również pojęcie „kopaliny współwystępującej” (np. art. 49z ust. 3 pkt 4; art. 134 ust. 3 pkt 2). Nie ma natomiast wątpliwości, że przedmiotem wniosku koncesyjnego (i w konsekwencji - wydobywania) mogą być wyłącznie te kopaliny towarzyszące i użyteczne pierwiastki śladowe, które znajdą się w granicach obszaru górniczego.
} 
wód podziemnych w ujęciu przy określonym sposobie eksploatacji, uwzględniająca ograniczenia związane $z$ wymaganiami ochrony środowiska $i$ warunkami techniczno-eksploatacyjnymi poboru wody"6. Wyraża się je w jednostkach objętości w jednostce czasu $\left(\mathrm{m}^{3} / \mathrm{h}\right)$. Oznacza to, że wielkość wspomnianych zasobów musi być ustalana odrębnie dla każdego przypadku, w praktyce - w drodze decyzji zatwierdzającej dokumentację hydrogeologiczną ujęcia wody. Rozwiązanie to dotyczy wyłącznie wód, które są kopalinami w rozumieniu art. 5 pr.g.g.

$\mathrm{Na}$ temat pojęcia „obszaru górniczego" i „terenu górniczego” zob. art. 6 ust. 1 pkt 5 i pkt 15 komentowanej ustawy. Trafnie przyjmuje H. Schwarz', że wspomniany obszar i teren są przestrzeniami trójwymiarowymi. W szczególności charakterystykę obszaru górniczego determinują warunki występowania złoża kopaliny. Zależnie od sytuacji w jego skład mogą wchodzić nieruchomości gruntowe, czego przykładem jest górnictwo odkrywkowe. W przypadku złóż zalegających głęboko co do zasady należy bronić zapatrywania, że utworzone dla ich wydobywania obszary górnicze nie obejmują nieruchomości gruntowych znajdujących się powyżej.

Warto przypomnieć, że żaden przepis komentowanej ustawy nie wskazuje wymagań, jakim miałyby odpowiadać „mapy górnicze”. Co prawda są one przedmiotem Polskich Norm, jednak stosowanie tych ostatnich nie jest obowiązkowe. W szczególności brak podstaw, by zakładać, że art. 26 (podobnie zresztą jak art. 24) pr.g.g. wprowadza nakaz korzystania z Polskich Norm dotyczących omawianej problematyki. $\mathrm{Z}$ niewiadomych powodów prawodawca nie był zainteresowany rozwiązaniami normatywnymi ${ }^{8} \mathrm{~W}$ analizowanej tu kwestii. W praktyce oznacza to wątpliwość co do sposobu określenia wymagań dla „map górniczych”. Skoro jednak nie zostały one ustalone prawem (w tym przez wprowadzenie obowiązku stosowania Polskich Norm), należy bronić zapatrywania, że wymagania te określa wnioskodawca, np. przez posłużenie się „legendą” objaśniającą użytą symbolikę. Komentowany przepis nie uprawnia natomiast organu koncesyjnego do żądania przedłożenia map w określonej skali. Wprawdzie źródłem wątpliwości może być rozporządzenie Ministra Środowiska z dnia 16 października 2014 r. w sprawie rejestru obszarów górniczych i zamkniętych podziemnych składowisk dwutlenku węgla9 ${ }^{9}$, które m.in. wskazuje wymagania dotyczące danych ujawnianych we wspomnianym rejestrze; brak jednak podstaw, by owe wymagania odnosić do treści wniosku koncesyjnego.

${ }^{6}$ Stownik hydrogeologiczny. Red. J. Dowgiałło, A.S. Kleczkowski, T. Macioszczyk, A. Różkowski. Państwowy Instytut Geologiczny, Warszawa 2002, s. 320.

${ }^{7}$ H. Schwarz: Prawo geologiczne i górnicze. Komentarz. T. 1: Art. 1-103. Salome, Wrocław 2013, s. 219.

${ }^{8} \mathrm{Na}$ przykład w formie rozporządzenia wykonawczego określającego wspomniane standardy albo normy prawnej nakazującej stosowanie wskazanych Polskich Norm.

${ }^{9}$ Dz.U. 2014, poz. 1469. 
Istotą geologicznych i hydrogeologicznych warunków wydobycia kopaliny jest przede wszystkim informacja o budowie (charakterystyce) złoża oraz o stanie otaczającego je środowiska. Okoliczności te (budowa złoża, stan otaczającego je środowiska, wpływ wydobycia na pozostałe elementy środowiska, ciśnienie wody, jej temperatura itd.) przesądzają o technologii udostępnienia i wydobycia złoża. Wydobywanie kopaliny ze złoża przeważnie wpływa na stan otaczającego je środowiska, głównie w zakresie stosunków wodnych. Każde wyrobisko górnicze powoduje efekt studni, do której napływa woda z otaczającego je środowiska. W konsekwencji trzeba odwadniać wyrobisko, jednym zaś ze sposobów pozbycia się napływających do niego wód jest ich wtłaczanie do górotworu. Pojęcie to zdefiniowane zostało jako „pozbycie się wód pochodzących z odwodnień wyrobisk górniczych, wykorzystanych wód leczniczych, wód termalnych, solanek, a także wód złożowych, w tym wód z podziemnych magazynów węglowodorów, z wyłączeniem wód technologicznych wykorzystywanych w magazynach węglowodorów zlokalizowanych w złożach soli kamiennej, polegające na ich wprowadzaniu otworami wiertniczymi do formacji geologicznych izolowanych od użytkowych poziomów wodonośnych" (art. 6 ust. 1 pkt 16b pr.g.g.). Wody z odwodnienia zakładów górniczych $-\mathrm{z}$ wyją̧tkiem wód wtłaczanych do górotworu, jeżeli rodzaje i ilość substancji zawartych w wodzie wtłaczanej do górotworu są tożsame $\mathrm{z}$ rodzajami i ilościami substancji zawartych w pobranej wodzie - $\mathrm{z}$ wyłączeniem niezanieczyszczonych wód pochodzących z odwodnienia zakładów górniczych, są ściekami (art. 16 pkt 6le Prawa wodnego $)^{10}$. Za sprawą prymitywnej techniki legislacyjnej definicję tę trudno uważać za dostatecznie komunikatywną. Nie powinno jednak być wątpliwości, że wtłaczane do górotworu wody, pochodzące z odwadniania wyrobisk górniczych, których skład jest tożsamy ze składem (jakościowo-ilościowym) wód pochodzących $z$ takiego odwodnienia i które nie zostały zanieczyszczone, nie są ściekami. Prawne uwarunkowania takiego zatłaczania mogą być określone w koncesji, co wyłącza stosowanie przepisów o korzystaniu z wód oraz o opłatach za korzystanie ze środowiska (art. 32 ust. 4 pkt 2 pr.g.g.).

W świetle art. 6 ust. 1 pkt 2 pr.g.g. informacją geologiczną „są dane i próbki geologiczne wraz z wynikami ich przetworzenia i interpretacji, w szczególności przedstawione $\mathrm{w}$ dokumentacjach geologicznych oraz zapisane na informatycznych nośnikach informacji”. Istotne jest, że elementem wniosku koncesyjnego może być tylko taka informacja geologiczna, której wyraz stanowi dokumentacja zatwierdzona $\mathrm{w}$ drodze decyzji organu administracji geologicznej ${ }^{11}$. Wnioskodawca ma obowiązek przedłożenia kopii takiej decyzji ${ }^{12}$, co niestety należy odczytać jako normatywny wyraz biurokratycznego wygodnictwa organów

${ }^{10}$ Ustawa z dnia 20 lipca 2017 r. - Prawo wodne (t.j. Dz.U. 2021, poz. 624 ze zm.).

${ }^{11}$ Bądź przyjęta pod rządem poprzedniego stanu prawnego w drodze zawiadomienia organu administracji geologicznej (art. 211 pr.g.g.).

${ }^{12}$ Bądź zawiadomienia o jej przyjęciu pod rządem dawnego stanu prawnego. 
koncesyjnych. Organ administracji geologicznej jest bowiem jednocześnie organem koncesyjnym i najczęściej to właśnie on podjął decyzję o zatwierdzeniu tej dokumentacji ${ }^{13}$, która przeważnie znajduje się w jego dyspozycji. Wyjątkowo, jeżeli doszło do zmiany właściwości rzeczowej organów administracji geologicznej, niekiedy może być inaczej. Nie ma jednak przeszkody, by dane pozwalające na ustalenie, czy doszło do zatwierdzenia takiej dokumentacji (a nadto jaka jest treść) ustalić $\mathrm{w}$ ramach współdziałania organów administracji publicznej, zgodnie z w art. $7 \mathrm{~b}$ Kodeksu postępowania administracyjnego ${ }^{14}$, czy też wykorzystując powszechnie dostępne systemy informacji o złożach kopalin. Stosownie do art. 21 ust. 2 pkt 34 lit. c ustawy z dnia 3 października 2008 r. o udostępnianiu informacji o środowisku i jego ochronie, udziale społeczeństwa $\mathrm{w}$ ochronie środowiska oraz o ocenach oddziaływania na środowisko ${ }^{15}$ dane o „kartach informacyjnych złóż kopalin, o których mowa w przepisach wydanych na podstawie art. 97 ust. 1 pkt 1" pr.g.g. ${ }^{16}$, są zresztą powszechnie dostępną informacją o środowisku i jego ochronie.

Ustawa nie daje odpowiedzi na pytanie, z jaką dokładnością trzeba sporządzić dokumentację złoża kopaliny stanowiącą podstawę uzyskania koncesji. Wiadomo natomiast, że załącznikiem do wniosku koncesyjnego (z wyjątkiem koncesji objętych kompetencjami starostów) musi być projekt zagospodarowania złoża. Do jego sporządzenia wymagane jest rozpoznanie złoża w kategorii co najmniej $\mathrm{C}$. Co więcej, taka dokumentacja określa m.in. warunki geologiczno-górnicze eksploatacji (§ 6 ust. 2 pkt 3 rozporządzenia Ministra Środowiska z dnia 1 lipca 2015 r. w sprawie dokumentacji geologicznej złoża kopaliny, z wyłączeniem złoża węglowodorów) $)^{17}$.

Co do zasady „prawo do informacji geologicznej” przysługuje Skarbowi Państwa (art. 99 ust. 1 pr.g.g.). Wyjątki dotyczą niektórych informacji geologicznych powstałych pod rządem dawnych przepisów. Ten, kto w wyniku wykonanych na swój koszt prac (geologicznych) prowadzonych na podstawie decyzji wydanych na podstawie ustawy ${ }^{18}$ lub prowadzonych na podstawie zgłoszenia (o którym mowa w art. 85 ust. 2 i art. 85a ust. 1) uzyskał informację geologiczną, ma prawo do nieodpłatnego korzystania z niej. Podlega ono jednak ograniczeniom w czasie. Przez okres trzech lat - licząc odpowiednio od dnia doręcze-

${ }^{13}$ Bądź pod rządem dawnego stanu prawnego sporządził zawiadomienie o jej przyjęciu.

${ }^{14}$ Ustawa z dnia 14 czerwca 1960 r. - Kodeks postępowania administracyjnego (t.j. Dz.U. 2021, poz. 735 ze zm.); dalej: k.p.a.

${ }_{15}$ Dz.U. 2021, poz. 247 ze zm.; dalej: u.o.o.ś.

${ }^{16} \mathrm{Z}$ nieznanych powodów rozwiązanie to nie dotyczy jednak złóż węglowodorów. Bezspornie jednak każda dokumentacja geologiczna jest „informacją o środowisku” w rozumieniu art. 8 u.o.o.ś.

17 Dz.U. 2015, poz. 987.

${ }^{18}$ Czyli odpowiednio po uzyskaniu koncesji na poszukiwanie lub rozpoznawanie złoża kopaliny bądź decyzji zatwierdzającej projekt (niekoncesjonowanych) robót geologicznych. 
nia decyzji zatwierdzającej dokumentację geologiczną - takiemu podmiotowi przysługuje wyłączne prawo do korzystania $\mathrm{z}$ informacji geologicznej $\mathrm{w}$ celu ubiegania się o wykonywanie działalności m.in. w zakresie wydobywania kopalin ze złóż, a także wydobywania węglowodorów w czasie trwania fazy wydobywania, o której mowa w art. 49v pkt 2 lit. b. Jeżeli jednak przed upływem terminu trzech lat podmiot, któremu przysługuje opisana wyżej „wyłączność”, uzyskał decyzję stanowiącą podstawę wykonywania działalności polegającej na „wydobywaniu”, zachowuje on wyłączne prawo do korzystania z informacji geologicznej przez czas określony w takiej decyzji oraz dodatkowo przez dwa lata od dnia utraty jej mocy. Odrębne wymagania dotyczą podziemnego składowania dwutlenku węgla (art. 99 ust. 3-4).

Przedstawione wyżej wymagania trudno ocenić jako dostatecznie komunikatywne. Przede wszystkim nie jest wystarczająco jasna istota wspomnianego prawa do „nieodpłatnego korzystania” z informacji geologicznej. Bezspornie jest to prawo podmiotowe, którego przedmiotem jest dobro o charakterze niematerialnym (a nie jego nośnik, zarówno papierowy, jak i cyfrowy). Wydaje się, że istotę owego prawa stanowi „używanie” wspomnianej informacji w każdym możliwym celu; w szczególności dotyczy to wykorzystywania jej w celach koncesyjnych. Prawo to przez trzy lata ma charakter wyłączny, co jednocześnie oznacza, że Skarb Państwa w czasie, w którym przysługuje omawiana „wyłączność", nie ma możliwości dokonywania dalszych rozporządzeń przysługującym mu prawem do informacji geologicznej. Dalsze szczegóły wykraczają poza zakres komentowanego art. 26 pr.g.g.

Powstaje z kolei pytanie, jak liczyć termin początkowy „wyłączności”. Literalnie rzecz biorąc, biegnie on od „dnia doręczenia decyzji zatwierdzającej dokumentację” (art. 99 ust. 3). Prawodawca ,zapomniał” jednak, że co do zasady decyzja nieostateczna nie powoduje przewidzianych nią skutków prawnych, chyba że nadano jej rygor natychmiastowej wykonalności. Prowadziłoby to do wniosku, iż bieg analizowanego terminu rozpoczyna się dopiero z dniem wykonalności decyzji zatwierdzającej dokumentację geologiczną. Istnieje zresztą obawa, że możliwość skorzystania przez wnioskodawcę z „wyłączności” będzie iluzoryczna. Przypomnieć należy, że większość przedsięwzięć w zakresie wydobywania kopalin zaliczona została do kategorii „mogących (zawsze, potencjalnie) znacząco oddziaływać na środowisko", a w konsekwencji niezbędnym elementem wniosku koncesyjnego staje się decyzja środowiskowa. Wystąpienie $\mathrm{z}$ wnioskiem o jej uzyskanie możliwe jest dopiero po zatwierdzeniu dokumentacji geologicznej złoża kopaliny. Wiadomo również, że nie są niczym nadzwyczajnym toczące się przez kilka lat postępowania w sprawie uzyskania owej decyzji. W praktyce szansa na skorzystanie $\mathrm{z}$,wyłączności” będzie więc ograniczona. Upływ wspomnianego terminu 3 lat nie pozbawia wnioskodawcy (który poniósł koszt wykonania prac stanowiących podstawę uzyskania informacji geologicznej) możliwości nabycia prawa do korzystania z niej odpłatnie 
(art. 99 ust. 2). Tak nabyte prawo nie ma jednak charakteru wyłącznego, nie można zatem wykluczyć, że Skarb Państwa, powołując się na art. 99 ust. 1, rozporządzi nim na rzecz innego podmiotu.

Wnioskodawca, który w okolicznościach wskazanych w art. 99 ust. 2 i nast. nie nabył prawa do korzystania z informacji geologicznej, może uzyskać je w drodze umowy zawartej ze Skarbem Państwa (art. 100 ust. 2-3a pr.g.g.). Powstaje natomiast pytanie, $w$ jaki sposób wnioskodawca ma wykazać istnienie wspomnianego prawa. W świetle art. 75 k.p.a. ,jako dowód w sprawie należy dopuścić wszystko, co może przyczynić się do wyjaśnienia sprawy, a nie jest sprzeczne z prawem. W szczególności dowodem mogą być dokumenty, zeznania świadków, opinie biegłych oraz oględziny” (§ 1). „Jeżeli przepis prawa nie wymaga potwierdzenia określonych faktów lub stanu prawnego w drodze zaświadczenia właściwego organu administracji, organ [...] odbiera od strony, na jej wniosek, oświadczenie złożone pod rygorem odpowiedzialności za fałszywe zeznania. Przepis art. $83 \S 3$ stosuje się odpowiednio" (§ 2). Co ważne, nakaz dołączenia do wniosku koncesyjnego dowodów „istnienia określonych w nim okoliczności” sformułowany został w art. 24 pr.g.g., określającym ogólne wymagania dotyczące wszystkich wniosków koncesyjnych. Wystarczającym dowodem „prawa do informacji geologicznej” będzie zatem wykazanie przez wnioskodawcę istnienia przesłanek określonych w art. 99 ust. 2 oraz nast. bądź powołanie się na umowę zawartą ze Skarbem Państwa, przeważnie zresztą reprezentowanym przez organ koncesyjny. Nie znajduje natomiast najmniejszych podstaw prawnych stosowana niekiedy praktyka żądania przez ów organ przekładania kopii decyzji stanowiących podstawę wykonania prac, w których wyniku doszło do pozyskania informacji geologicznej, bądź umów zawartych ze Skarbem Państwa, mocą których rozporządził on przysługującym mu prawem do informacji geologicznej (zob. także art. 7b k.p.a.).

„Prawo do wydobywania kopalin” jest elementem prawa podmiotowego przysługującego do przestrzeni, w granicach której ma być wykonywana zamierzona działalność. W odniesieniu do górnictwa odkrywkowego sprawa znacznie się komplikuje. W zasadzie takim prawem podmiotowym w odniesieniu do złóż niestanowiących przedmiotu prawa własności górniczej jest prawo własności nieruchomości gruntowej (jej części, zespołu nieruchomości gruntowych lub ich części) bądź pochodne od niego prawa podmiotowe, których treścią jest możliwość korzystania z nieruchomości i pobierania jej pożytków. Inaczej mówiąc, w świetle art. 26 ust. 2 pkt 2 pr.g.g. wnioskodawca musi wykazać, że takie prawo mu przysługuje albo że dysponuje dowodem przyrzeczenia jego ustanowienia. Dowodami tych okoliczności mogą być zwłaszcza dokumenty urzędowe (np. wypis z księgi wieczystej) bądź prywatne (głównie umowy). Wymagania te nie dotyczą natomiast wydobywania węgla brunatnego. W komentowanym przepisie jednoznacznie posłużono się określeniami „prawo do nieruchomości” oraz „dowód przyrzeczenia jego ustanowienia”. Innymi słowy, wnioskodawca 
musi legitymować się niezbędnym prawem podmiotowym lub przyrzeczeniem jego ustanowienia. Powstaje pytanie, czy wystarczającym dowodem tej okoliczności jest oświadczenie właściciela nieruchomości, że nie sprzeciwia się zamiarowi objęcia jej obszarem górniczym. Co prawda orzekając pod rządem dotychczasowego $^{19}$ stanu prawnego, Wojewódzki Sąd Administracyjny w Warszawie przyjął, że takie oświadczenie właściciela jest wystarczające ${ }^{20}$, ale w aktualnym stanie prawnym taka ocena zdecydowanie musi zostać zakwestionowana ${ }^{21}$.

Jeżeli wspomniane prawo do „nieruchomości gruntowej” ma powstać w drodze umowy, to niewątpliwie musi ona zostać zawarta z podmiotem, który ma możliwość rozporządzania takowym prawem (podmiotowym). Wnioskodawcy nie zawsze zwracają na to uwagę, czego przyczyną przeważnie jest nieuregulowany stan prawny wielu nieruchomości gruntowych. W praktyce ustanowienie takiego prawa (które może przybrać postać np. dzierżawy) następuje za wynagrodzeniem, ustalanym najczęściej w drodze negocjacji wnioskodawcy z właścicielem. Generuje to problemy. Bezspornie właściciele (użytkownicy wieczyści) nieruchomości położonych $\mathrm{w}$ granicach projektowanych (wnioskowanych) oraz istniejących obszarów górniczych są stronami postępowań koncesyjnych dotyczących wydobywania kopalin (art. 41 pr.g.g.). W konsekwencji mają oni (i ich pełnomocnicy) prawo dostępu do akt sprawy, np. do umów ustanawiających prawo do korzystania z nieruchomości bądź przyrzekających jego ustanowienie oraz do informacji o związanym z tym wynagrodzeniu. Może to powodować eskalację żądań finansowych pod adresem wnioskodawców czy też dążeń do rozwiązania już zawartych umów. W rezultacie wnioskodawcy niejednokrotnie domagają się objęcia treści umów „klauzulą poufności” (art. 28ha pr.g.g.). Zasadność takich żądań można ocenić wyłącznie na podstawie analizy konkretnego stanu faktycznego, wiele wskazuje jednak na to, że problem ten daje się rozwiązać przez umiejętną redakcję umów o korzystanie z nierucho-

${ }^{19}$ Czyli pod rządem ustawy z dnia 4 lutego 1994 r. - Prawo geologiczne i górnicze (Dz.U. 1994, nr 27, poz. 94 ze zm.). Obowiązujący wówczas art. 18 pkt 2 przewidywał, że o ile ustawa nie stanowi inaczej, wniosek o udzielenie koncesji powinien zawierać określenie prawa wnioskodawcy do terenu (przestrzeni), w ramach którego projektowana działalność ma być wykonywana, lub prawa, o którego ustanowienie ubiega się wnioskodawca.

20 Prawomocny wyrok WSA w Warszawie z dnia 3 listopada 2009 r., sygn. VI SA/Wa 735/09. Tak samo przyjmuje H. Schwarz, Prawo geologiczne i górnicze..., s. 221.

${ }^{21}$ Już pod rządem dawnego stanu prawnego NSA przyjmował, że nie można wbrew woli właściciela gruntów uzyskać koncesji na poszukiwanie i rozpoznawanie złóż kruszywa naturalnego znajdującego się w granicach jego nieruchomości. Przeciwne rozwiązanie byłoby sprzeczne $\mathrm{z}$ regułami postępowania administracyjnego wynikającymi m.in. z art. 7 k.p.a., który zawiera ogólną klauzulę załatwienia sprawy administracyjnej zgodnie z interesem społecznym. Jeżeli wnioskodawca we wniosku nie tylko nie określił prawa do terenu, ale wręcz oświadczył, że o żadne prawo do przedmiotowego terenu się nie ubiega, to organ koncesyjny powinien wydać decyzję negatywną (wyrok NSA z dnia 17 kwietnia 1998 r., sygn. II SA 1695/97). 
mości (przyrzeczenie ustanowienia takiego prawa), co powinno spowodować bezprzedmiotowość wymagań przewidzianych w art. 28 ha.

Niezbędnym elementem wniosków o koncesję na wydobywanie kopalin, z wyłączeniem wniosków objętych kompetencjami starosty, jest projekt zagospodarowania złoża (dalej: pzz.). Ma on określać wymagania w zakresie racjonalnej gospodarki złożem kopaliny głównej, kopalin towarzyszących oraz technologii eksploatacji zapewniającej ograniczenie ujemnych wpływów na środowisko. Inaczej mówiąc, dokument ten stanowi część wniosku koncesyjnego zmierzającą do realizacji m.in. zasady prewencji (art. 6 Prawa ochrony środowiska) $^{22}$ oraz określający wymagania w zakresie racjonalnego wykorzystywania środowiska (art. 3 pkt 13 w zw. z art. 125-126 pr.o.ś.). Szczegółowe wymagania, jakim powinien odpowiadać taki dokument, określają przepisy wykonawcze ${ }^{23}$. Sporządza się go „w granicach projektowanego obszaru górniczego”. Określa on:

1) optymalny wariant racjonalnego wykorzystania zasobów złoża, w szczególności przez kompleksowe i racjonalne wykorzystanie kopaliny głównej i kopalin towarzyszących, z uwzględnieniem:

a) geologicznych warunków występowania złoża,

b) technicznych możliwości oraz ekonomicznych uwarunkowań wydobywania kopaliny,

c) przewidywanego sposobu likwidacji zakładów górniczych, ochrony zasobów pozostawionych w złożu po zakończeniu eksploatacji oraz rekultywacji gruntów po działalności górniczej;

2) działania niezbędne $w$ zakresie ochrony środowiska, w tym technologię eksploatacji zapewniającą ograniczenie ujemnych wpływów na środowisko;

3) zasoby przemysłowe, będące częścią zasobów bilansowych lub pozabilansowych złoża, a w przypadku wód leczniczych, termalnych i solanek - zasobów eksploatacyjnych złoża, w granicach projektowanego obszaru górniczego lub wydzielonej części złoża przewidzianej do zagospodarowania, które mogą być przedmiotem uzasadnionej technicznie i ekonomicznie eksploatacji przy uwzględnieniu wymagań określonych w przepisach prawa, w tym dotyczących ochrony środowiska;

4) zasoby nieprzemysłowe, będące częścią zasobów bilansowych złoża niezaliczoną do zasobów przemysłowych w obszarze przewidzianym do zagospodarowania, których eksploatacja może stać się uzasadniona w wyniku zmian technicznych, ekonomicznych lub zmian w przepisach prawa, w tym dotyczących wymagań ochrony środowiska;

5) straty w zasobach przemysłowych i nieprzemysłowych, będące częścią tych zasobów przewidzianą do pozostawienia w złożu, której na skutek za-

${ }^{22}$ Ustawa z dnia 27 kwietnia 2001 r. - Prawo ochrony środowiska (Dz.U. 2021, poz. 1973 ze zm.); dalej: pr.o.ś.

${ }^{23}$ Rozporządzenie Ministra Środowiska z dnia 24 kwietnia 2012 r. w sprawie szczegółowych wymagań dotyczących projektów zagospodarowania złóż (Dz.U. 2012, poz. 511). 
mierzonego sposobu eksploatacji nie można wyeksploatować w przewidywalnej przyszłości w sposób uzasadniony technicznie i ekonomicznie;

6) zasoby operatywne dla złóż kopalin stałych, stanowiące zasoby przemysłowe pomniejszone o przewidywane straty.

Udostępnianie i wydobywanie zasobów złoża należy projektować w sposób umożliwiający zagospodarowanie w przyszłości części złoża nieobjętej zagospodarowaniem i zagospodarowanie zasobów złóż występujących w jego sąsiedztwie (§ 1).

Projekt zagospodarowania złoża składa się z trzech części: opisowej, graficznej i tabelarycznej. Część opisowa uwzględnia zamierzony sposób eksploatacji, rodzaj kopaliny i warunki geologiczne prowadzenia eksploatacji oraz zawiera odpowiednio:

1) informacje o położeniu i granicach udokumentowanego złoża oraz zasobach złoża wraz z charakterystyką uwarunkowań geograficznych, prawnych i ochrony środowiska wpływających na ograniczenie możliwości eksploatacji złoża lub części złoża i na lokalizację obiektów zakładu górniczego, określenie lokalizacji obiektów zakładu górniczego ograniczających możliwość eksploatacji;

2) określenie granic projektowanego obszaru i terenu górniczego, a w przypadku wód uznanych za kopaliny - z uwzględnieniem warunków hydrodynamicznych;

3) uzasadnienie granic zamierzonej eksploatacji, przedstawienie sposobu i miejsca składowania nadkładu, projektowanych filarów ochronnych, ze wskazaniem obiektów objętych ochroną, uzasadnieniem ich granic oraz określeniem warunków ewentualnej eksploatacji złoża objętego filarem ochronnym;

4) określenie miejsca i sposobu udostępnienia złoża, proponowanych systemów eksploatacji kopaliny głównej, kopalin towarzyszących i współwystępujących, z uwzględnieniem warunków geologiczno-górniczych, w szczególności hydrogeologicznych i geologiczno-inżynierskich, wraz z określeniem spodziewanych dopływów wody, sposobów odwadniania i jakości odpompowywanej wody oraz wpływu zamierzonej eksploatacji na powierzchnię terenu i obiekty budowlane;

5) określenie zagrożeń mogących wpłynąć na bezpieczeństwo eksploatacji i ochronę zasobów oraz sposobów przeciwdziałania tym zagrożeniom, z uwzględnieniem (zależnie od potrzeb) warunków gazowych i geotermicznych;

6) określenie przewidywanej wielkości wydobycia kopalin i danych o kolejności wybierania poszczególnych części złoża, a w złożach wielopokładowych - poszczególnych pokładów (w celu ich zabezpieczenia przed niszczącą podbudową);

7) określenie warunków wtłaczania wód do górotworu, jeżeli w związku z wydobywaniem kopaliny ze złoża projektuje się wtłaczanie do górotworu wód 
pochodzących z odwodnienia zakładów górniczych, wód złożowych lub wykorzystanych solanek, wód leczniczych oraz termalnych;

8) określenie kryteriów klasyfikacji zasobów złoża do przemysłowych lub nieprzemysłowych przy istniejących uwarunkowaniach geologicznych, technicznych i ekonomicznych, określenie sposobu ustalania i wielkości zasobów przemysłowych i nieprzemysłowych wraz ze wskazaniem zakresu ich możliwych zmian;

9) określenie rodzaju i wielkości przewidywanych strat w zasobach przemysłowych, stopnia wykorzystania zasobów przemysłowych złoża wraz z uzasadnieniem oraz dla złóż kopalin stałych - wielkości zasobów operatywnych;

10) określenie stopnia zamierzonego wykorzystania zasobów kopalin towarzyszących i współwystępujących;

11) określenie zasad, sposobu i zakresu ochrony zasobów nieprzemysłowych i niezbędnych warunków dla ich przekwalifikowania do zasobów przemysłowych lub strat w wyniku prowadzonej eksploatacji;

12) określenie przewidywanego sposobu likwidacji zakładu górniczego, ochrony pozostawionych zasobów w złożu po zakończeniu eksploatacji oraz przewidywanego sposobu rekultywacji gruntów po działalności górniczej;

13) charakterystykę warunków ekonomicznych prowadzenia eksploatacji i wykorzystania złoża, a gdy te czynniki decydują o klasyfikacji zasobów do przemysłowych i nieprzemysłowych - przedstawienie szczegółowej analizy ekonomicznej;

14) kopie dokumentów (w formie załączników), których treść ma istotne znaczenie dla opracowanego projektu.

Część graficzna pzz., stosownie do zamierzonego sposobu eksploatacji i rodzaju kopaliny, zawiera:

1) mapę lub mapy sytuacyjno-wysokościowe sporządzone w skali umożliwiającej szczegółowe przedstawienie obszaru przewidzianego do zagospodarowania, z zaznaczeniem granic złoża, granic projektowanego obszaru i terenu górniczego, granic sąsiednich obszarów i terenów górniczych dla tych samych kopalin, granic nieruchomości gruntowych, do których przysługuje wnioskodawcy tytuł prawny, obiektów chronionych i granic proponowanych filarów ochronnych, proponowanego miejsca lub miejsc udostępnienia złoża oraz proponowanego miejsca lub miejsc składowania nadkładu. Na wspomnianej mapie zaznacza się wyrobiska górnicze w przypadku wcześniejszego prowadzenia robót górniczych; miejsca wyrobisk udostępniających i eksploatacyjnych oraz obszarów złoża wyeksploatowanego dla złóż zagospodarowanych; granice obszaru spływu wód do ujęcia, granice oddziaływania ujęcia i granice obszaru zasobowego dla wód podziemnych uznanych za kopaliny;

2) mapę lub mapy sytuacyjno-wysokościowe powierzchni z oznaczeniem przewidywanych zmian powstałych na skutek eksploatacji, oznaczeniem stref 
i wielkości przewidywanych deformacji terenu, jego przydatności do zabudowy i zagospodarowania;

3) mapy rozmieszczenia zasobów zakwalifikowanych do przemysłowych, nieprzemysłowych oraz strat związanych z wcześniejszą eksploatacją;

4) przekroje geologiczno-górnicze, a dla złóż eksploatowanych odkrywkowo - przekroje zawierające oznaczenie zasobów przemysłowych, nieprzemysłowych i strat;

5) mapy przedstawiające sposób korzystania ze środowiska, sposoby jego przekształceń i ochrony.

Część tabelaryczna pzz. zawiera obliczenia zasobów przemysłowych i nieprzemysłowych w obszarze przewidzianym do zagospodarowania, a w przypadku złóż kopalin stałych - również zasobów operatywnych i przewidywanych strat oraz tabelę zbiorczą wyników obliczeń. Wspomniane dane uwzględniają w zasadzie stan na dzień 31 grudnia roku poprzedzającego rok sporządzenia pzz.

Sporządzenie pzz. nie jest „pracą” ani „robotą” geologiczną, a w konsekwencji nie wymaga posiadania kwalifikacji zawodowych w zakresie geologii czy też górnictwa bądź ratownictwa górniczego (art. 50 i nast. pr.g.g.).

Jeżeli przedmiotem wnioskowanej koncesji ma być wydobywanie ze złóż kopalin wymienionych $\mathrm{w}$ art. 10 ust. 1 pr.g.g. (z wyłączeniem węglowodorów), pzz. podlega zaopiniowaniu przez organ nadzoru górniczego. Opinia powinna zostać wyrażona w terminie $14 \mathrm{dni}$, pod rygorem przyjęcia, że organ ten nie zgłasza uwag pod adresem omawianego dokumentu. Opinię - bądź odpowiednio oświadczenie o jej braku czy też sposobie jej uwzględnienia (odmowy uwzględnienia) - należy dołączyć do wniosku koncesyjnego (art. 27 ust. 3a-3b). Natomiast jeżeli wniosek koncesyjny dotyczy wydobywania kopalin innych niż wymienione w art. 10 ust. 1 (przykładem mogą być koncesje marszałka województwa), opinia organu nadzoru górniczego jest zbędna.

Zdaniem wojewódzkich sądów administracyjnych informacje zawarte w projekcie zagospodarowania złoża:

- są informacją o środowisku i jego ochronie ${ }^{24}$;

- mogą stanowić tajemnicę przedsiębiorstwa ${ }^{25}$.

Wymagań dotyczących pzz. nie stosuje się do wniosków o koncesje objęte właściwością starostów. Za sprawą dalszych rozwiązań do wydobywania kopalin prowadzonego na podstawie takich koncesji nie stosuje się przepisów o planach ruchu zakładu górniczego (art. 105 ust. 2 pkt 1 pr.g.g.). W konsekwencji wniosek o koncesję starosty określa także:

${ }^{24}$ Prawomocny wyrok WSA w Warszawie z dnia 11 marca 2014 r., sygn. IV SA/Wa 2136/13.

${ }^{25}$ Prawomocny wyrok WSA w Gliwicach z dnia 27 września 2018 r., sygn. IV SA/Gl $599 / 18$. 
- wymagania określone w art. 108 ust. 2, czyli stanowiące treść planu ruchu zakładu górniczego;

- „prognozowany” (czyli przewidywany) sposób likwidacji zakładu górniczego, uwzględniający obowiązki określone w art. 129 ust. 1, czyli stanowiące przedmiot planu ruchu likwidowanego zakładu górniczego. Rozwiązanie to nie wyłącza natomiast wymagań znajdujących się poza Prawem geologicznym i górniczym, zwłaszcza dotyczących rekultywacji gruntów, gospodarki wodnej itd.

Powstaje pytanie, z jaką dokładnością należy rozpoznać złoże kopaliny koncesjonowane przez starostę. Wiadomo, że elementem wniosku koncesyjnego w takiej sprawie nie jest projekt zagospodarowania złoża. W konsekwencji odwoływanie się do rozpoznania złoża w stopniu niezbędnym do sporządzenia wspomnianego projektu staje się bezprzedmiotowe. Bezspornie jednak wniosek ma m.in. określać „geologiczne i hydrogeologiczne warunki wydobycia”, a więc informacje będące przedmiotem dokumentacji geologicznej złoża kopaliny, sporządzonej z dokładnością rozpoznania również co najmniej C1. Inaczej mówiąc, rozpoznanie złoża w kategorii C1 lub wyższej jest przesłanką uzyskania każdej koncesji na wydobywanie kopaliny, z wyjątkiem węglowodorów.

Jeżeli element wniosku koncesyjnego stanowi decyzja środowiskowa, wynikające z niej uwarunkowania mogą kształtować treść wniosku, zwłaszcza elementy wskazane w art. 26 ust. 1 pkt 2-3, które bez wątpienia mieszczą się w pojęciu „środowiskowych uwarunkowań przedsięwzięcia” (art. 71 ust. 1, art. 80 i nast. u.o.o.ś.).

W istocie komentowany art. 26 pr.g.g. określa rozwiązania zmierzające do realizacji przewidzianego Prawem ochrony środowiska nakazu ochrony złóż kopalin, rozumianej jako ich racjonalne wykorzystywanie ${ }^{26}$.

Art. 27.

1. We wniosku o udzielenie koncesji na podziemne bezzbiornikowe magazynowanie substancji albo podziemne składowanie odpadów określa się również:

1) rodzaj, ilość oraz charakterystykę substancji albo odpadów;

2) aktualne i przewidywane warunki geologiczne, hydrogeologiczne i geologiczno-inżynierskie; w przypadku działalności polegającej na składowaniu odpadów promieniotwórczych warunki te odnoszą się do lokalizacji, budowy, eksploatacji, zamknięcia oraz do okresu po zamknięciu składowiska odpadów promieniotwórczych;

${ }^{26}$ Wedle art. 125 pr.o.ś. złoża kopalin podlegają ochronie polegającej na racjonalnym gospodarowaniu ich zasobami oraz kompleksowym wykorzystaniu kopalin, w tym kopalin towarzyszących. Z kolei art. 126 ust. 1 pr.o.ś. nakazuje prowadzić eksploatację złoża kopaliny w sposób gospodarczo uzasadniony, przy zastosowaniu środków ograniczających szkody w środowisku i przy zapewnieniu racjonalnego wydobycia i zagospodarowania kopaliny. 
3) technologię magazynowania albo składowania;

4) projektowane położenie obszaru górniczego i terenu górniczego, przedstawione zgodnie $\mathrm{z}$ wymaganiami dotyczącymi map górniczych, z zaznaczeniem granic podziału terytorialnego kraju.

2. Do wniosku, o którym mowa w ust. 1, dołącza się dowód istnienia prawa do korzystania $\mathrm{z}$ informacji geologicznej, jakie $\mathrm{w}$ zakresie niezbędnym do prowadzenia zamierzonej działalności przysługuje wnioskodawcy, oraz kopie decyzji zatwierdzających dokumentacje geologiczne.

3. Do wniosku o udzielenie koncesji na podziemne skladowanie odpadów promieniotwórczych dołącza się zezwolenie Prezesa Państwowej Agencji Atomistyki na budowę składowiska odpadów promieniotwórczych.

Istotą podziemnego bezzbiornikowego magazynowania substancji jest ich przechowywanie w naturalnych (zwłaszcza powstałych w wyniku eksploatacji węglowodorów) lub sztucznych (najczęściej powstałych w wyniku wypłukania złóż soli kamiennej) pustkach we wnętrzu skorupy ziemskiej. W praktyce przedmiotem takiego „magazynowania” jest gaz ziemny. Określenie rodzaju, ilości i charakterystyki wspomnianych substancji nie powinno budzić większych problemów. Cykl związanej z tym działalności obejmuje napełnianie podziemnego magazynu, przechowywanie zgromadzonej tam substancji, a następnie jej wydobywanie. Warto jednak zwrócić uwagę, że „magazynowanie” nie ma nic wspólnego z „magazynowaniem odpadów” 27 w rozumieniu art. 3 ust. 1 pkt 5 ustawy z dnia 10 grudnia 2012 r. o odpadach.

Stosownie do art. 3 pkt 6 ustawy o odpadach ${ }^{28}$ przez „odpady” rozumie się każdą substancję lub przedmiot, których posiadacz ${ }^{29}$ zamierza się pozbyć, pozbywa się lub do których pozbycia się jest obowiązany. Obowiązek wspomnianego pozbycia się może wynikać tylko z ustawy bądź podjętej na jej podstawie decyzji. Ustawy o odpadach nie stosuje się natomiast m.in. do:

- gazów i pyłów wprowadzanych do atmosfery (pkt 1);

- mas ziemnych lub skalnych przemieszczanych w związku z wydobywaniem kopalin ze złóż, jeżeli koncesja na wydobywanie kopalin ze złóż lub plan ruchu zakładu górniczego, lub miejscowy plan zagospodarowania przestrzennego dla terenu górniczego określają warunki i sposób ich zagospodarowania (pkt 11);

${ }^{27}$ Rozumianego jako „czasowe przechowywanie odpadów”.

${ }^{28}$ Ustawa z dnia 14 grudnia 2012 r. o odpadach (Dz.U. 2021, poz. 779 ze zm.); dalej: u.o.

29 Jest nim wytwórca odpadów lub osoba fizyczna, osoba prawna oraz jednostka organizacyjna nieposiadająca osobowości prawnej będąca w posiadaniu odpadów; domniemywa się, że władający powierzchnią ziemi jest posiadaczem odpadów znajdujących się na nieruchomości (art. 3 pkt 19 u.o.). Wartość tej definicji jest problematyczna, „posiadacza” zdefiniowano bowiem jako tego, kto jest „w posiadaniu odpadów”. 
- dwutlenku węgla przeznaczonego do podziemnego składowania w celu przeprowadzenia projektu demonstracyjnego wychwytu i składowania dwutlenku węgla w rozumieniu art. 1 ust. 3 pr.g.g. (pkt 12).

Odpowiedź na pytanie, jak rozumieć wspomniane „zagospodarowanie”, nie jest prosta. Ustawa o odpadach definiuje „gospodarowanie” nimi jako „zbieranie, transport, przetwarzanie odpadów, łącznie z nadzorem nad tego rodzaju działaniami, jak również późniejsze postępowanie z miejscami unieszkodliwiania odpadów oraz działania wykonywane w charakterze sprzedawcy odpadów lub pośrednika w obrocie odpadami”. „Przetwarzaniem” są „procesy odzysku lub unieszkodliwiania, $w$ tym przygotowanie poprzedzające odzysk lub unieszkodliwianie" (art. 3 ust. 1 pkt 2-3 oraz pkt 21). Inaczej mówiąc, jeżeli koncesja na wydobywanie kopalin lub plan ruchu zakładu górniczego, lub miejscowy plan zagospodarowania przestrzennego przewidują, że masy ziemne lub skalne przemieszczane w związku z wydobywaniem kopalin są ,przemieszczane”, a zwłaszcza wykorzystane do wypełniania wyeksploatowanych wyrobisk, nie są one odpadami.

W świetle Prawa atomowego ${ }^{30}$ do odpadów promieniotwórczych zaliczają się materiały stałe, ciekłe lub gazowe zawierające substancje promieniotwórcze lub skażone tymi substancjami, których wykorzystanie nie jest przewidywane ani rozważane, zakwalifikowane do kategorii odpadów wymienionych w art. $47^{31}$, w tym wypalone paliwo jądrowe przeznaczone do składowania (art. 3 pkt 22 pr.at.). Prawo atomowe dzieli składowiska odpadów promieniotwórczych na powierzchniowe i głębokie, jednocześnie dość rygorystycznie określając przesłanki ustalenia lokalizacji tych ostatnich (art. 53a-53b) s. $^{32}$ co determinuje, rzecz jasna, możliwość uzyskania koncesji na ich podziemne składowanie. Przyjęta tam

30 Ustawa z dnia 29 listopada 2000 r. (Dz.U. 2019, poz. 1792 ze zm.).

31 Który określa przesłanki zaliczania odpadów promieniotwórczych do kategorii niskoaktywnych, średnioaktywnych oraz wysokoaktywnych.

32 Składowiska odpadów promieniotwórczych lokalizuje się w sposób uniemożliwiający otrzymanie przez osoby spośród ogółu ludności w ciągu roku dawki skutecznej (efektywnej) ze wszystkich dróg narażenia przekraczającej wartość $0,1 \mathrm{mSv}$, a nadto tylko na obszarach, na których środowisko przyrodnicze podlega łagodnie przebiegającej ewolucji, a warunki nią kształtowane mogą być w przypadku składowiska głębokiego wiarygodnie prognozowane przez 10000 lat. Składowisko głębokie lokalizuje się w formacjach geologicznych posiadających miąższość i rozciągłość niezbędne dla obiektów składowiska i filarów ochronnych. Składowisk odpadów promieniotwórczych nie lokalizuje się:

1) na obszarach występowania lub zagrożonych oddziaływaniem gwałtownych zjawisk, w tym:

a) powodzi o większym prawdopodobieństwie pojawienia się niż dla wody 1000-letniej,

b) zwiększonej aktywności sejsmicznej naturalnej lub indukowanej działalnością człowieka,

c) zwiększonej aktywności tektonicznej oraz na przebiegu stref uskokowych,

d) ruchów masowych ziemi,

e) osiadania lub zapadania się terenu,

f) zjawisk krasowych lub sufozyjnych,

g) intensywnej erozji wgłębnej lub powierzchniowej; 
terminologia nie w pełni koresponduje z przewidzianą przez Prawo geologiczne i górnicze. Można bronić poglądu, że w istocie składowisko „głębokie” (wedle terminologii Prawa atomowego) jest tożsame z „podziemnym” (w rozumieniu Prawa geologicznego i górniczego). „Wykonywanie działalności związanej narażeniem” polegającej m.in. na „budowie, eksploatacji lub zamknięciu składowisk odpadów promieniotwórczych" wymaga zezwolenia Prezesa Państwowej Agencji Atomistyki (art. 4 ust. 1 pkt 3; art. 5).

Postępowanie $\mathrm{z}$ odpadami wydobywczymi reguluje ustawa $\mathrm{z}$ dnia 10 lipca 2008 r. o odpadach wydobywczych ${ }^{33}$. Pojęcie to oznacza odpady pochodzące z poszukiwania, rozpoznawania, wydobywania, przeróbki i magazynowania kopalin ze złóż (art. 3 ust. 1 pkt 2 u.o.wyd.). Niezbędną przesłanką ustalenia, że dany przedmiot (substancja itd.) jest „odpadem wydobywczym”, jest uznanie go za odpad w rozumieniu art. 3 ust. 1 pkt 6 u.o., czyli który pochodzi ,z poszukiwania, rozpoznawania, przeróbki i magazynowania kopalin". Rozwinięcie szczegółów wykracza poza ramy niniejszego komentarza.

Ustawa o odpadach wprowadza następującą hierarchię (sekwencję) sposobów postępowania $\mathrm{z}$ odpadami:

1) prewencja (zapobieganie powstawaniu odpadów);

2) przygotowywanie do ponownego użycia;

3) recykling - odzysk, w ramach którego odpady są ponownie przetwarzane na produkty, materiały lub substancje wykorzystywane w pierwotnym celu lub innych celach; obejmuje to ponowne przetwarzanie materiału organicznego (recykling organiczny), ale nie obejmuje odzysku energii i ponownego przetwarzania na materiały, które mają być wykorzystane jako paliwa lub do celów wypełniania wyrobisk (art. 3 pkt 23); jego szczególną postacią jest recykling organiczny;

4) inne procesy odzysku - jakikolwiek proces, którego głównym wynikiem jest to, aby odpady służyły użytecznemu zastosowaniu przez zastąpienie innych materiałów (które w przeciwnym wypadku zostałyby użyte do spełnienia danej funkcji) lub w wyniku którego odpady są przygotowywane do speł-

2) w obrębie obszarów aglomeracji miejskich i skupionego osadnictwa oraz na obszarach o wyższej wartości społecznej (kulturowej, rekreacyjnej i zdrowotnej);

3) w strefach ochronnych ujęć wody i obszarach ochronnych zbiorników wód śródlądowych;

4) w strefach zasilania głównych i użytkowych zbiorników wód podziemnych;

5) w podziemnych wyrobiskach górniczych powstałych w wyniku wydobycia kopalin;

6) na terenach górniczych wyznaczonych do działalności polegającej na wydobywaniu kopalin ze złóż;

7) na obszarach, na których udokumentowano złoża kopalin, których miejsce występowania może być niesprzyjające dla lokalizacji składowiska;

8) w obszarach morskich Rzeczypospolitej Polskiej w rozumieniu ustawy z dnia 21 marca 1991 r. o obszarach morskich Rzeczypospolitej Polskiej i administracji morskiej.

${ }^{33}$ Dz.U. 2021, poz. 1972; dalej: u.o.wyd. 
nienia takiej funkcji w danym zakładzie lub ogólnie w gospodarce (art. 3 pkt 14);

5) unieszkodliwianie - proces niebędący odzyskiem, nawet jeżeli wtórnym skutkiem takiego procesu staje się odzysk substancji lub energii (art. 18); jednym ze sposobów unieszkodliwiania odpadów jest ich składowanie.

W konsekwencji nie można nazwać składowaniem umieszczenia odpadów w wyrobisku górniczym w celu innym niż ich unieszkodliwianie; najczęściej będzie ono formą ich odzysku. Bezspornie zaś istotą podziemnego składowania odpadów jest ich unieszkodliwienie ${ }^{34}$.

Skoro we wniosku o każdą z koncesji wymienionych w komentowanym artykule należy określić aktualne i przewidywane warunki geologiczne, hydrogeologiczne i geologiczno-inżynierskie, to wnioskodawca musi dysponować rozpoznaniem geologicznym przestrzeni, w granicach której ma być prowadzona zamierzona działalność, a w szczególności dokumentacją hydrogeologiczną i geologiczno-inżynierską (art. 90 ust. 1 pkt 2 lit. e oraz art. 91 ust. 1 pkt 3). Elementami wniosku koncesyjnego w omawianych sprawach są dowód istnienia prawa wnioskodawcy do informacji geologicznej oraz kopia decyzji zatwierdzającej dokumentację. Za nieporozumienie trzeba jednak uznać ocenę, że wystarczy w tym celu przedłożyć kserokopię wspomnianej decyzji ${ }^{35}$ (zob. komentarz do art. 26). Przez „technologię magazynowania albo składowania” należy rozumieć metodę prowadzenia omawianej działalności, w tym przewidywane środki zabezpieczające środowisko.

W świetle definicji przyjętych $\mathrm{w}$ art. 6 ust. 1 pkt 5 oraz pkt 15 nie ma wątpliwości, że pojęcia „obszaru górniczego” i „terenu górniczego” odnoszą się również do podziemnego magazynowania i składowania. Na temat sposobu rozumienia sformułowania ,zgodnie z wymaganiami dotyczącymi map górniczych" zob. komentarz do art. 24 oraz art. 26 pr.g.g.

${ }^{34}$ Tak też zauważają trafnie F. Plewa, Z. Mysłek: Regulacje prawne podziemnego składowania odpadów. „Przegląd Górniczy” 2015, nr 12, s. 32 i nast. Błędnie przyjmuje natomiast M. Kulik (Komentarz do niektórych przepisów ustawy - Prawo geologiczne i górnicze. Komentarz do art. 176. W: Pozakodeksowe przestępstwa przeciwko zasobom przyrody i środowisku. Komentarz. Red. M. Mozgawa. LEX/el 2017), że podziemne składowanie odpadów jest metodą ich przechowywania.

${ }_{35}$ Jak twierdzi G. Klimek (Prawo geologiczne i górnicze. Komentarz Lex. Red. B. Rakoczy. Wolters Kluwer, Warszawa 2015, s. 150). 


\section{Literatura}

Agopszowicz A.: Zarys systemu prawnego górnictwa. Wyd. 5 przejrzał i uzupełnił Aleksander Lipiński. Uniwersytet Śląski, Katowice 1991.

Danecka D., Kierzkowska J.S., Trzcińska D.: Ograniczenia działalności gospodarczej ze względu na ochrone przyrody. Wolters Kluwer, Warszawa 2018.

Dobrowolski G., Lipiński A., Mikosz R., Radecki G.: Gospodarowanie geologicznymi zasobami środowiska w świetle zasady zrównoważonego rozwoju. Zagadnienia prawne. Red. G. Dobrowolski. Wydawnictwo Uniwersytetu Śląskiego, Katowice 2018.

Glapa W., Korzeniowski J.I.: Mały leksykon górnictwa odkrywkowego. Wydawnictwa i Szkolenia Górnicze Burnat \& Korzeniowski, Wrocław 2005.

Goss M.: Nadzór i regulacja sektora ropy i gazu. Wolters Kluwer, Warszawa 2016.

Górski M., Pchałek M., Radecki W., Jerzmański J., Bar M., Urban S., Jendrośka J.: Prawo ochrony środowiska. Komentarz. Wydawnictwo C.H. Beck, Warszawa 2011.

Jaśkowska M., Wilbrandt-Gotowicz M., Wróbel A.: Komentarz aktualizowany do Kodeksu postępowania administracyjnego. LEX/el 2019.

Kaczmarski L.: Instytucja zajęcia stanowiska przez inny organ przy wydawaniu decyzji administracyjnej przez organ właściwy w sprawie. „Casus”, zima 2018, nr 91, s. 27-41.

Kulik M., Komentarz do niektórych przepisów ustawy - Prawo geologiczne i górnicze. W: Pozakodeksowe przestepstwa przeciwko zasobom przyrody $i$ środowisku. Komentarz. Red. M. Mozgawa. LEX/el 2017.

Lipiński A.: Prawne podstawy geologii i górnictwa. Wolters Kluwer, Warszawa 2019.

Lipiński A., Mikosz R.: Komentarz do ustawy Prawo geologiczne i górnicze. Wyd. 2. ABC, Warszawa 2003.

Mikosz R.: Granice koncesjonowania działalności regulowanej prawem geologicznym i górniczym. „Przegląd Prawa Ochrony Środowiska” 2009, nr 2, s. 39-57.

Mikosz R.: Koncesja na wydobywanie kopalin jako prawny instrument ochrony środowiska. „Gospodarka Surowcami Mineralnymi” 2008, T. 24, z. 2/4, s. 9-25.

Nieć M.: Koncesjonowanie poszukiwania, rozpoznawania i eksploatacji złóż kopalin a wymagania racjonalnej gospodarki. „Przegląd Geologiczny” 2018, T. 66, nr 3, s. 170-175.

Plewa F., Mysłek Z.: Regulacje prawne podziemnego składowania odpadów. „Przegląd Górniczy" 2015, nr 12, s. 32-35.

Prawo geologiczne i górnicze. Komentarz LEX. Red. B. Rakoczy. Wolters Kluwer, Warszawa 2015.

Prawo przedsiębiorców. Komentarz. Red. A. Pietrzak. Wolters Kluwer, Warszawa 2019.

Przeszło E., Wolska H.: Koncesje w prawie geologicznym i górniczym. „Przegląd Ustawodawstwa Gospodarczego" 2019, nr 6, s. 33-39.

Ratajczak T., Hycnar E.: Kopaliny towarzyszace w złożach węgla brunatnego. T. 1: Geologiczno-surowcowe aspekty zagospodarowania kopalin towarzyszacych. Wydawnictwo IGSMiE PAN, Kraków 2017.

Schwarz H.: Prawo geologiczne i górnicze. Komentarz. T. 1: Art. 1-103. Salome, Wrocław 2013.

Stownik hydrogeologiczny. Red. J. Dowgiałło, A.S. Kleczkowski, T. Macioszczyk, A. Różkowski. Państwowy Instytut Geologiczny, Warszawa 2002.

Stefanowicz J.A.: Niesprawność i dtugotrwałość postępowań na ścieżce do koncesji eksploatacyjnej i zatwierdzenia planu ruchu - rozpoznanie i klasyfikacja istotnych czynników nieefektywności tych procesów. „Przegląd Geologiczny” 2018, T. 66, nr 4, s. 229-234. 
Szamałek K.: Kopaliny towarzyszace - wydobywanie, składowanie i zbywanie w świetle obowiqzujacego prawa. „Górnictwo Odkrywkowe” 2001, nr 2/3, s. 1-9.

Szamałek K.: Zarys ewolucji polskiego prawa poszukiwania $i$ wydobywania kopalin $w$ latach 1991-2015. „Biuletyn Państwowego Instytutu Geologicznego” 2015, vol. 465, s. 21-34.

Szędzielarz A.: Ochrona i zagospodarowanie strategicznych zasobów węgla kamiennego inne spojrzenie. (Artykut polemiczny). „Bezpieczeństwo Pracy i Ochrona Środowiska w Górnictwie" 2017, nr 11, s. 16-23.

Uberman R.: Kopaliny towarzyszące w złożach węgla brunatnego. T. 2: Prawno-ekonomiczne oraz górnicze aspekty zagospodarowania kopalin towarzyszacych. Wydawnictwo IGSMiE PAN, Kraków 2017.

Uberman R., Nieć M.: Kopaliny towarzyszace - problemy dokumentowania, wydobycia i opłat eksploatacyjnych. „Górnictwo Odkrywkowe” 2014, nr 2/3, s. 32-39.

Wąsiewski G.: Zasada racjonalnej gospodarki złożami kopalin w prawie polskim - próba rekonstrukcji. „Przegląd Ustawodawstwa Gospodarczego” 2017, nr 9, s. 16-27.

Wojtulek P., Kocowski T., Małecki W.: Prawo geologiczne i górnicze. Wydawnictwo C.H. Beck, Warszawa 2020.

Wybrane problemy prawa geologicznego i górniczego. Red. B. Rakoczy. Wolters Kluwer. Warszawa 2016.

Aleksander Lipiński

\title{
Comment on Art. 26-27 of Geological and Mining Law of 9 June 2011
}

\author{
Summary
}

Article 26 sets out detailed requirements of the license applications for mining of minerals from deposits. These include, in particular, information about the mineral deposit, way and size of the mining, the rights to use the land and the right to the geological information. An appendix to such application is the "deposit development plan", determining the way of rational use of the deposit and environmental protection. Similar requirements apply to applications for the underground non-reservoir storage of substances and underground waste depositing (Art. 27).

Key words: license application for mining of minerals, deposit development plan

\section{Александр Липиньски}

\section{Комментарий к ст. 26-28 закона о геологическом и горном праве от 9 июня 2011 г., Зак. вестник за 2020 г., п. 1064 с изм.}

Резюме

В статье 26 излагаются подробные требования к заявкам на получение концессии на добычу полезных ископаемых в месторождении. К ним относятся, в частности, информация о месторождении полезных ископаемых, право на геологическую информацию и право на пользование недвижимым имуществом. Приложение представляет собой проект по 
развитию месторождения, в котором излагаются принципы его рационального использования с учетом требований охраны окружающей среды. Аналогичные требования касаются заявок на получение концессии на подземное хранение веществ без использования резервуаров и подземное хранение отходов (ст. 27).

Кл юче вы е с лов а: заявка на получение концессии на добычу полезных ископаемых на месторождении, проект по управлению месторождением

\title{
Aleksander Lipiński
}

\section{Commento agli articoli 26-28 della legge del 9 giugno 2011 - Legge geologica e mineraria}

\author{
Sommario
}

L'articolo 26 stabilisce i requisiti specifici per le domande di concessione per estrarre un minerale da un giacimento. Essi comprendono in particolare le informazioni sul giacimento minerario, il diritto alle informazioni geologiche e il diritto di utilizzare la proprietà. Un'appendice è il piano di sviluppo del deposito, che specifica le regole per il suo uso razionale, tenendo conto dei requisiti di protezione ambientale. Requisiti simili si applicano alle domande di concessione per lo stoccaggio sotterraneo di sostanze senza serbatoi e lo stoccaggio sotterraneo di rifiuti (articolo 27).

Parole chiave: domanda di licenza per l'estrazione di un minerale dal giacimento, piano di sviluppo del giacimento 